\title{
THE DISTRIBUTION AND BIODIVERSITY OF FISHES IN LEBAK PAMPANGAN SWAMP SOUTH SUMATRA PROVINCE
}

\author{
Dina Muthmainnah', Zulkifli Dahlan², Robiyanto H. Susanto², \\ Abdul Karim Gaffar ${ }^{1}$ and Dwi P. Priadi ${ }^{2}$ \\ ${ }^{1}$ Researcher of Research Institute for Inland Fisheries \\ ${ }^{2}$ Professor of Sriwijaya University \\ Received August 30-2013; Received in revised form December 02-2013; Accepted May December 12-2013
}

\begin{abstract}
This research was conducted to evaluate the fish distribution and biodiversity within three types of swamp ecosystem with different water sources in Pampangan Sub-district during July to December 2011. The field observation were conducted in three different types of swamp. Ecological data and samples were collected from three sampling points in each swamp type. Parameters including local distribution, diversity index, similarity index, evenness and species richness, were analyzed. The results show a number of 9,723 fishes corresponding to 46 species were collected, the fish categorized into 16 families belonging to five orders. Eight species were found in all type of swamps i.e. Mystus nemurus, Channa striata, Cyclocheilchthys apogon, Cyclocheilichthys armatus, Pristolepis fasciata, Puntius lineatus, Osteochillus hasselti, and Trichogaster pectoralis. A diversity index of fishes in Pampangan Swamp ranged from 2.31 to 2.85, indicating moderate values. The evenness index was high more than $50 \%$. The highest similarity was found between type 1 and type 3 of (0.43). The highest diversity index (2.85) found in type 2 of swamp indicates the swamp in more stable condition.
\end{abstract}

KEYWORDS: Distribution, fish biodiversity, Lebak Pampangan Swamp, South Sumatra

\section{INTRODUCTION}

Swamps are a half-way world between terrestrial and aquatic ecosystems and exhibit some of the characteristics of each. They form part of a continuous gradient between uplands and open water (Smith, 1980). Swamps are valuable as sources, sinks, and transformers of a multitude of chemical, biological, and genetic materials, and also for fish and wildlife protection (Mitsch \& Gosselink, 1986).

Djajadireja et al. (1977) estimated that there are about 4,000 fishes species in the Indonesian waters, at least 950 freshwater or brackish water species can be found in Western Indonesia and Borneo (Kotellat et al., 1993). Utomo et al. (2007) and Husnah et al. (2008) further reported that there are 233 species of freshwater fishes of South Sumatra waters, which are grouped into 111 genera within 38 families.

The most important of swamps plays major roles in the landscape by providing unique habitats for a wide variety of flora and fauna. About two-third of the fish and shellfish species commercially harvested are associated with swamps. The degree of dependence on swamps varies widely with species. Many freshwater species spawn in swamp. Some important species are permanent residents, and others are merely transients that feed in swamps when the opportunity arises. Virtually all of the freshwater

Corresponding author:

Researcher of Research Institute for Inland Fisheries

Jl. Beringin, No. 08, Mariana Palembang species are somewhat dependent on swamps, often spawning in riparian forests during flooding.

South Sumatra Province has huge swamp area about 1.1 million hectares (Sumsel in figure, 2005). Pampangan district of South Sumatra constiutes a large area of swamp ecosystem, the ecosystem beside as water storage and wild life habitat also used by any development sector such as agriculture (rice fields), capture fisheries, aquaculture and animal husbandry (swamp buffalos and duck).

Studies of freshwater fishes in swamp ecosystem were limited to scattered works on capture fisheries and even these have been largely restricted to some of the major floodplain swamp of river systems. As fishing ground the swamps are habitat of many kinds of fish species, both black fish and white fish. This research was conducted to evaluate fish distribution within three types of swamp ecosystems with different water sources in Pampangan district.

\section{MATERIALS AND METHODS}

The research was conducted in three different types of swamp in Pampangan District of South Sumatra Province (Figure 1). According to sources of water those swamps were divided into three types: 1) the swamp inundated by flood water from Komering river, 2) the swamp with peat soils inundated by rain 
water called Lebak Deling, and 3) the swamp inundated by both flood water from Komering river and rain water from Lebak Deling. Ecological data and samples for laboratory study were collected.

Fishes were sampled by any kinds of fishing gears used by local fishermen such as: aill nets, barrier with pot traps, filtering nets, and simple pot traps. The samples were collected from July to Desember 2011. The fish were preserved in $10 \%$ formalin solution and transfering to Laboratory. Identification was carried out by meristemic and morphological observations using reference books (Kottelat et al., 1993; Weber \& de Beaufort. 1931).

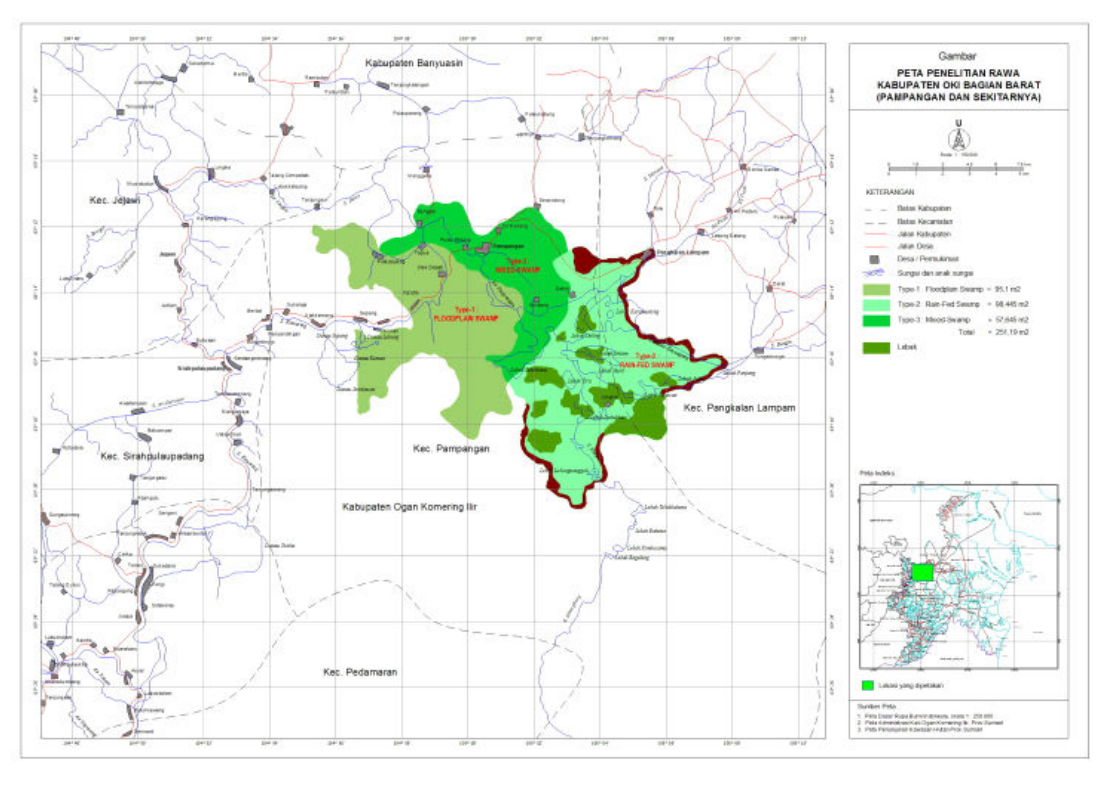

Figure 1. Research Site Map.

Species richness was used as the index for the estimation of species diversity as well as for comparisons of diversity across swamp areas, as the relative abundance for the species may not give the true abundance for the communities. $T h$ e identified fish species were analyzed using some biological indices as follows:

a. Similarity Index (Jaccard Index) (Magguran, 1988)

where:

$$
C_{j}=j /(a+b-j)
$$

$\mathrm{j}=$ the number of species common to both side

$a=$ the number of species in site $A$

$\mathrm{b}=$ the number of species in site $B$

b. Diversity Index (Shannon and Weiner Index) (Magguran, 1988)

where:

$$
\mathrm{H}=- \text { "pi In pi }
$$

$$
\begin{aligned}
\mathrm{pi}=\mathrm{ni} / \mathrm{N}\left(\mathrm{N}=\begin{array}{l}
\text { total number of individuals of } \\
\text { species } \mathrm{i})
\end{array}\right. \\
\mathrm{N} \quad \begin{array}{l}
\text { total number of individuals of all } \\
\text { species }
\end{array}
\end{aligned}
$$

c. Evenness (Pielou Index) (Magguran, 1988)

$$
\mathrm{E}=\mathrm{H}^{\prime} / \ln \mathrm{S}
$$

where:

$$
\begin{aligned}
& \mathrm{S}=\text { total number of species } \\
& \mathrm{H}=\text { diversity index }
\end{aligned}
$$

d. Species Richness (Margalef Index)

where:

$$
d=(S-1) / \ln N
$$

$\mathrm{S}=$ total number of species

$\mathrm{N}=$ Total number of individuals of all species

\section{RESULTS}

Within 3 types of swamp ecosystems a number of 46 species of fishes and prawn was found. The higher diversity of 31 species was found in the type 2 of swamp, while the lowest diversity of 16 species was found in the type 1 of swamp. However, in the type 3 of swamp a medium diversity of 27 species was found (Table 1).

The indices of species richness, diversity and evenness in each types of swamp was shown in Table 2.

The similarity index for fish community between different type of swamp was shown in Table 3, the values of index were 0.13 to 0.44 . 
The Distribution..... of Fishes in Lebak Pampangan Swamp South Sumatera Province (Muthmainnah D., et al)

Table 1. The number of fishes (individuals) from three swamp types.

\begin{tabular}{|c|c|c|c|c|c|c|}
\hline \multirow{2}{*}{ No. } & \multirow{2}{*}{ Family } & \multirow{2}{*}{ Species } & \multirow{2}{*}{ Local name } & \multicolumn{3}{|c|}{ Swamp types } \\
\hline & & & & 1 & 2 & 3 \\
\hline 1 & Anabantidae & Anabas testudineus & Betok & 0 & 173 & 157 \\
\hline 2 & Bagridae & Mystus nigriceps & Berengit & 123 & 0 & 0 \\
\hline 3 & Bagridae & Mystus planiceps & Baung & 200 & 55 & 295 \\
\hline 4 & Bagridae & Mystus wolffi & Lundu & 0 & 43 & 0 \\
\hline 5 & Belontiidae & Belontia hasselti & Selincah & 0 & 367 & 0 \\
\hline 6 & Belontiidae & Trichogaster trichopterus & Sepat Mata Merah & 0 & 0 & 303 \\
\hline 7 & Belontiidae & Trichogaster pectoralis & Sepat siam & 51 & 156 & 427 \\
\hline 8 & Channidae & Channa lucius & Bujuk & 0 & 431 & 0 \\
\hline 9 & Channidae & Channa marulioides & Jalai & 0 & 13 & 0 \\
\hline 10 & Channidae & Channa melanosoma & Serko & 0 & 121 & 0 \\
\hline 11 & Channidae & Channa micropeltes & Toman & 0 & 85 & 39 \\
\hline 12 & Channidae & Channa pleuropthalmus & Serandang & 0 & 15 & 0 \\
\hline 13 & Channidae & Channa striata & Gabus & 120 & 540 & 197 \\
\hline 14 & Clariidae & Clarias batrachus & Lele & 0 & 0 & 16 \\
\hline 15 & Clariidae & Clarias nieuhofi & Keli Panjang & 0 & 10 & 0 \\
\hline 16 & Cyprinidae & Barbichthys laevis & Bentulu & 0 & 0 & 26 \\
\hline 17 & Cyprinidae & Barbodes schwanefeldii & Lampam & 24 & 0 & 165 \\
\hline 18 & Cyprinidae & Cyclocheilichtys apogon & Keperas merah & 44 & 311 & 526 \\
\hline 19 & Cyprinidae & Cyclocheilichtys armantus & Keperas putih & 20 & 31 & 496 \\
\hline 20 & Cyprinidae & Cyclocheilichtys enoplos & Lumajang & 12 & 0 & 0 \\
\hline 21 & Cyprinidae & Hampala ampalong & Tenggago & 2 & 0 & 0 \\
\hline 22 & Cyprinidae & Labeo chrysophekadion & Sihitam & 1 & 0 & 4 \\
\hline 23 & Cyprinidae & Osteochillus lineatus & Tembelikat & 0 & 0 & 16 \\
\hline 24 & Cyprinidae & Osteochillus schlegeli & Semuruk & 0 & 42 & 0 \\
\hline 25 & Cyprinidae & Osteochilus hasseltii & Palau & 54 & 45 & 67 \\
\hline 26 & Cyprinidae & Osteochilus microcephalus & Kojam & 0 & 0 & 55 \\
\hline 27 & Cyprinidae & Parachela oxygaster & Siamis & 0 & 74 & 1 \\
\hline 28 & Cyprinidae & Puntius hexazona & Elang & 24 & 56 & 0 \\
\hline 29 & Cyprinidae & Puntius lineatus & Kemuringan & 124 & 661 & 150 \\
\hline 30 & Cyprinidae & Puntius tetrazona & Pirik Cawang & 0 & 24 & 0 \\
\hline 31 & Cyprinidae & Rasbora borneensis & Seluang & 0 & 290 & 0 \\
\hline 32 & Eleotridae & Oxyeleotris marmoratus & Betutu & 0 & 0 & 1 \\
\hline 33 & Helostomatidae & Helostoma temminckii & Sapil & 0 & 456 & 384 \\
\hline 34 & Nandidae & Nandus nebulosus & Setambun & 0 & 465 & 0 \\
\hline 35 & Notopteridae & Notopterus notopterus & Putak & 0 & 0 & 25 \\
\hline 36 & Pangasiidae & Pangasius djambal & Patin & 0 & 0 & 12 \\
\hline 37 & Pristolepididae & Pristolepis fasciata & Kepor/Sepatung & 64 & 379 & 73 \\
\hline 38 & Schilbidae & Pseudeutropius brachypopterus & Riu & 0 & 256 & 45 \\
\hline 39 & Siluridae & Kryptoperus Ischilbeides & Lais Kukur & 0 & 44 & 0 \\
\hline 40 & Siluridae & Kryptopterus apogon & Lais Muncung & 16 & 0 & 91 \\
\hline 41 & Siluridae & Kryptopterus cryptopterus & Lais Kaca & 0 & 0 & 24 \\
\hline 42 & Siluridae & Kryptopterus macrochepalus & Lais Tapah & 12 & 29 & 0 \\
\hline 43 & Siluridae & Wallago leeri & Tapah & 0 & 15 & 0 \\
\hline 44 & Tetraodontidae & Tetraodon sp & Buntal & 0 & 1 & 0 \\
\hline 45 & Palaemonidae & Macrobrachium rosenbergii & Udang & 0 & 6 & 2 \\
\hline 46 & Palaemonidae & Macrobrachium sp & Udang Serengkek & 0 & 25 & 16 \\
\hline
\end{tabular}


Table 2. Indices of species richness, diversity and evenness in three types of swamp ecosystem.

\begin{tabular}{lccc}
\hline & Type 1 & Type 2 & Type 3 \\
\hline Total of species & 16 & 31 & 27 \\
Total of individu & 891 & 5,219 & 3,613 \\
Species richness (d) & 2.21 & 3.50 & 3.17 \\
Diversity (H) & 2.31 & 2.85 & 2.65 \\
Pielou's evenness (E) & 0.84 & 0.83 & 0.80 \\
\hline
\end{tabular}

Table 3. Similarity index of fishes community in three types of swamp ecosystems.

\begin{tabular}{ccc}
\hline No. & Types of Swamp Ecosystems & Similarity Index (C) \\
\hline 1. & Type 1 and 2 & 0.13 \\
2. & Type 2 and 3 & 0.33 \\
3. & Type 1 and 3 & 0.44 \\
\hline
\end{tabular}

\section{DISCUSSION}

\section{Distribution and Species Composition}

Taxonomically, the 44 species of fish were grouped into 15 family belongs to five Order, and two species of prawn were member of a family. Fish Families consist of several number of species: Cyprinidae (16 species $=34.78 \%)$, Channidae $(6$ species $=13.04 \%)$, Siluridae $(5$ species $=10.87 \%)$ and Anabantoidei $(5$ species $=10.87 \%)$.

As comparison, Duangsawasdi et al. (2004) reported that fish community in swamp of Nong Han Thailand was consisted of $29.85 \%$ Cyprinidae, $5.85 \%$ Channidae, $0.94 \%$ Siluridae and $63 \%$ of others. In other location, Sulistiyanto et al. (2007) also found Cyprinidae and Siluridae as major inhabitant in swamp areas of Kalimantan. This finding is also supported by Lowe-McConnel (1987), revealing that freshwater fishes in Asia and Africa are dominated by member of family Cyprinidae and Siluridae.

Eight species were found in all type of swamps i.e. Mystus nemurus, Channa striata, Cyclocheilchthys apogon, Cyclocheilichthys armatus, Pristolepis fasciata, Puntius lineatus, Osteochillus hasselti, and Trichogaster pectoralis. This indicates that those species have a wide range of tolerance to different swamp condition.

There were six species of snakehead fish of Genus Channa found in type 2 of swamp, while in swamp of type 1 and 3 it is found only one and two species, respectively. This indicates that Snakehead fish of Genus Channa might be tolerable to acidic black water in swamp with peat soils. Payne (1986) mentioned that swamp dweller fish are tolerant to low $\mathrm{pH}$ condition and high $\mathrm{CO}_{2}$ level due to their hemoglobins which has high affinity to $\mathrm{O}_{2}$ and low sensitivity to $\mathrm{CO}_{2}$. Change in water quality could affect non swamp dweller fish which are intolerant to typically swamp waters.
Peter et al. (1994) conducted an intensive survey in part of the North Selangor peat swamp forest yielded 47 fish species, of which 14 are probably stenotopic taxa. These include four undescribed species and several new records for western Peninsular Malaysia.

It is well known that most Southeast Asian rivers, as well as those in the Indian subcontinent, are dominated by Cyprinids and Balitorids, whereas African Rivers as well as lakes abound with an astounding number of Cichlids and Characids (Bhat, 2003).

\section{Diversity index}

Amongs three types of swamp, the type 2 had highest species richness and diversity index while in type 1 has highest Pielou's Evenness. It means that Lebak Deling had smaller environmental stress, and provided more economic benefit (Magurran, 1988).

The Type 2 swamp, a permanent swamp areas with peat soils, indicates that the swamp is more stable ecosystem with minimum human intervention which can support fish life. While in type 1 and type 3 swamps are floodplain area which are inundated only during wet season, and during dry season the area were developed into rice field or vegetable plots.

The diversity is partly a function of the variety of habitats; the more varied habitats tend to be inhabited by a large number of species than less variable ones. Secondly the older habitats usually contain more species than younger ones. Increased stability permits an increase in species richness and species diversity, a change from environmental to biotic regulation of community structure, and the addition of another trophic compartment (Kushlan, 1976). 
Complexity of community structure due to the habitat heterogeneity may remain a high species density (Arrington \& Weinemuller, 2003). The increased species richness during the stable period would be the result of migration of species into swamp area from ponds and canals, which under present conditions are most stable habitats within the ecosystem.

Emmanuel \& Modupe (2010) studied on fish community structure in three tributaries of River Ore, also found different diversity indices as estimated from the three tributaries. The diversity is partly a function of the variety of habitats; the more varied habitats tend to be inhabited by a large number of species than less variable ones, low diversity indices of fish species indicated low fish species diversity.

Shannon-Weiner index $(H)$ affects both number of species and evenness of their population, diversity increases as both increases. Diversity is maximum when all species that made up the community are equally abundant (i.e. have a similar population sizes).

\section{Similarity}

The similarity index for fish community between different type of swamp were 0.13 to 0.44 , it means the fish community in three different swamp consists a low similarity or a different community (Magguran, 1988).

A high similarity indicates that there are few species differences between sites, yielding low diversity values. Different species usually behave differently and can have strongly variable effects on their resources such as food. A numerical differences between two localities in one species may be much more important than the difference in another species (Wolda, 1981).

The high diversity of fish species represents a variety of suitable habitat and food supplies, able to support many different species (Washington, 1984). Similarity indices may be better indicators of fish community change than diversity indices since the former reflect changes in the relative abundance of species in common and large temporal changes in a community structure which can occur without changing the value of its diversity index. Low similarity index indicates that fish community in three swamps were not similar.

\section{CONCLUSION}

Fish community in three types of Pampangan Swamps composed of 46 species belonging to 16 families of five orders. Eight species were found in all type of swamps i.e. Mystus nemurus, Channa striata, Cyclocheilchthys apogon, Cyclocheilichthys armatus, Pristolepis fasciata, Puntius lineatus, Osteochillus hasselti, and Trichogaster pectoralis. Swamp type 2 has the highest diversity index indicating more stable the swamps ecosystem.

\section{ACKNOWLEDGEMENT}

The present study was partly funded by the Ministry of Marine and Fisheries, Republic of Indonesia. The paper was presented in $1^{\text {st }}$ International Seminar Indonesian Ichthyological Society, in Makassar in 2012.

\section{REFERENCES}

Arrington, D.A. \& K.O. Weimuller. 2003. Organization and Maintenance of Biological Diversity in Neotropical Floodplain Rivers. In: Welcomme, R. \& T. Petr (ed). Proceedings of the Second International Symposium on the Management of Large Rivers for Fisheries Volume II. FAO Regional Office for Asia and the Pasific. Bangkok. Thailand. RAP. Publication 2004/17.

Bain, M.B. \& J.T. Finn. 1988. Stream Flow Regulation and Fish Community Structure. Ecology 69(2): 382392.

Bhat, A. 2003. Diversity and Composition of Freshwater Fishes in River Systems of Central Western Ghats, India. Environmental Biology of Fishes 68: 25-38.

Duangsawasdi, S., B. Sricharoendham, P. Kaewjaroon, M. Aimsab, W. Somchan \& N. Promkhruan. 2004. Ecology and Fish Community in Nong Han Swamp, Sakon Nakhon Province. Thai Fisheries Gazette (Jan-Feb 2004). ISSN: 0125-6297.

Djajadireja, R., S. Fatimah \& Z. Arifin. 1977. Economical Important Fish Species. Ditjen Perikanan. Departemen Pertanian. Jakarta.

Emmanuel, L.O. \& O.O. Modupe. 2010. Fish Diversity in Three Tributaries of River Ore, South West, Nigeria. World Journal of Fish and Marine Sciences 2 (6): 524-531. ISSN 2078-4589. 
Husnah, E. Nurhayati \& Ni.K.Suryati. 2008. Diversity Morphological Characters and Habitat of Fish in Musi River Drainage Area. South Sumatra. 440 p.

Lowe-McConnell, R.H. 1987. Ecological Studies in Tropical Fish Communities. Melbourne: Cambridge University Press.

Kottelat, M., A.J. Whitten; S.N. Kartikasari \& S. Wirjoatmojo. 1993. Freshwater Fishes of Western Indonesia and Sulawesi. Periplus Edition-EMDI Project. Jakarta.

Kushlan, J.A. 1976. Environment Stability and Fish Community Diversity. Ecology. Volume 57. Number 4. 821-825.

Magguran, A. E. 1988. Ecological Diversity and Its Measurement. Princeton University Press. Princeton. New Jersey. 179 p.

Mehner, T., M. Diekmann, U. Brannick \& R.Lemcke. 2005. Composition of Fish Community in German Lakes as Related to Lake Morphology, Trophic State, Shore structure and Human-use Intensity. Freshwater Biology. (50): 70-85.

Mitsch, W.J. \& Gosselink, J.G. 1986. Wetlands. van Nostrand Reinhold Company. New York.

Payne, A.I. 1986. The Ecology of Tropical Lake and Rivers. Chichester: Princeton University Press.

Peter, K.L.Ng., J.B. Tay \& K.K.P. Lim. 1994. Diversity and Conservation of Blackwater Fishes in Peninsular Malaysia, Particularly in the North Selangor Peat Swamp Forest. Hydrobiologia 285: 203-218. Eds: Satekumar, A., N. Marshall \& D.J. Macintosh. Ecology and Conservation of Southeast Asian Marine and Freshwater Environements Including Wetlands. Kluwer Academic Publishers. Belgium.
Smith, H.K. 1980. Coastal Habitat Development in the Dredged Material Research Program. In Rehabilitation and Creation of Selected Coastal Habitats. J.C. Lewis \& E.W. Bunce, eds. US.Fish \& Wildlife Service. Biol. Service Program. EWS/ OBS-80/27. p.117-125.

Sulistiyanto, B., D. Soedharma, M.F. Rahardjo \& Sumardjo. 2007. The Effect of Seasonality on Fish Species Composition and Abundance in Rungan River Floodplain, Palangkaraya, Central Kalimantan. Biodiversitas. Volume 8. Nomor 4. p270-273. ISSN: 1412-033X.

Sumsel in Figure. 2005. Collaboration between Bappeda South Sumatera and BPS South Sumatera Province, Palembang.

Utomo, A.D., N. Muflikhah, S. Nurdawati, M.F. Rahardjo \& S. Makmur. 2007. Ichthyofauna in Musi River South Sumatra. Research Institute for Inland Fisheries. Jakarta. $380 \mathrm{p}$.

Washington, H.G. 1984. Diversity, Biotic and Similarity Indices: A Review with Special Relevance to Aquatic Ecosystem. Water Res. 18:653-694.

Weber, M. \& L.F.de Beaufort. 1931. The Fishes of the Indo Australian Archipelago. E.J. Brill. Laiden. 6: $448 \mathrm{p}$.

Wolda, H. 1981. Similarity indices, sample size and diversity. Oecologia, 50. p 296-302. 